Костова H. I., кандидат юридичних наук, доцент кафбедри иивільного права Національного університету "Одеська юридична академія»

\title{
ІНФОРМАЦІЯ 3 ОБМЕЖЕНИМ ДОСТУПОМ ЗА СВОЇМ НОРМАТИВНО-ПРАВОВИМ РЕЖИМОМ
}

\begin{abstract}
Анотація. Стаття присвячена розгляду питання про теоретичний рівень розробки категорії «інформація за своїм нормативно-правовим режимом» у науці цивільного права. Зокрема, було розглянуто, що слід розуміти під правовим режимом інформації як об'єкта цивільного права, правову природу та характерні ознаки інформації. Також розглядаються різновиди інформації, особливості встановлення правового режиму інформації, місце інформації в системі об'єктів цивільних прав.

Ключові слова: інформація 3 обмеженим доступом, правовий режим, інформація, конфіденційна інформація, комерційна таємниця, ноу-хау.
\end{abstract}

Постановка проблеми. Вже досить довгий час у всіх країнах світу здійснюються зусилля щодо формування правового режиму об'єктів інформації. Вважається, що якщо ця проблема не вирішується, то, мабуть, слід шукати нові напрями або шляхи формування правового режиму нетипових об'єктів, зокрема й інформації (конфіденційної інформації).

Під правовим режимом інформації, а також конфіденційної інформації (у вигляді комерційної таємниці та ноу-хау), слід розуміти «врахування» законодавцем природних властивостей і ознак, які їм притаманні.

Саме 3 цими властивостями чинне цивільне законодавство й пов'язує певні правові наслідки. Однак проблема полягає ще й у тому, що, по-перше, термін «інформація» не є винятково юридичним терміном, $і$ їй (інформації) притаманні такі властивості-ознаки, які визначають іiі правовий режим і цивільному праву взагалі невідомі. По-друге, різним видам інформації притаманні свої особливі ознаки, відмінні від ознак «інформації, як такої». Цивільно-правовий режим інформації вичерпуватиметься лише цивільно-правовим регулюванням, направленим на неї.

Аналіз останніх досліджень і публікацій. Належне функціонування інформаційної сфери є запорукою розвитку суспільства. Забезпечення цих процесів є завданням правових норм, які покликані забезпечити захист інтересів усіх учасників інформаційних відносин. Такі інтереси в окремих випадках не співпадають. Прикладом цьому може служити співвідношення права на інформацію та право власників інформації на обмеження іiі поширення. 3 погляду науки окремі аспекти обмеження доступу до інформації та права на інформацію розкривали М. Агарков, С. Алексєєв, В. Брижко, Л. Воєводін, В. Грибанова, О. Звєрєва, Р. Калюжний, Л. Кузенко, А. Савицька, А. Пазюк, Н. Устименко, Я. Шевченко, М. Швець та інші науковці.

Метою статті $\epsilon$ визначення нормативно-правового режиму інформації з обмеженим доступом у зв'язку з його ознаками, відмінностями та особливостями.

Виклад основного матеріалу дослідження. Інформація з обмеженим доступом - це відомості конфіденційного або таємного характеру, правовий статус яких передбачений законодавством України і доступ до яких правомірно обмежений власником таких відомостей. Інформація з обмеженим доступом за своїм правовим режимом поділяється на конфіденційну і таємну. Конфіденційна інформація - це відомості, які знаходяться у володінні, користуванні або розпорядженні окремих фізичних чи юридичних осіб і поширюються за їх бажанням відповідно до передбачених ними умов. Таке визначення закріплене Законом України «Про інформацію», але, на нашу думку, має певні недоліки. По-перше, в перелік суб' єктів права власності конфіденційної інформації не включено державу, яка також володіє відомостями конфіденційного характеру. По-друге, визначення слід доповнити конструкцією «відомості, що не становлять передбаченої законом таємниці». Таємна інформація - це інформація, що містить відомості, які становлять державну та іншу передбачену законом таємницю (банківську, комерційну, службову, професійну, адвокатську тощо), розголошення якої завдає шкоди особі, суспільству і державі. Конфіденційну інформацію можна поділяти на таку, яка є власністю держави, і конфіденційну інформацію, яка не належить державі. До видів таємної інформації належать: державна таємниця, комерційна таємниця, банківська таємниця, службова таємниця, професійна таємниця, адвокатська таємниця, інші види таємниць.

Відповідно до чинного законодавства України комерційною таємницею $є$ інформація, яка $є$ секретною в тому розумінні, що вона в цілому чи в певній формі та сукупності іiі складників $є$ невідомою та не є легкодоступною для осіб, які звичайно мають справу з видом інформації, до якого вона належить; у зв'язку з цим має комерційну цінність та була предметом адекватних наявним обставинам заходів щодо збереження іiі секретності, вжитих особою, яка законно контролює цю інформацію.

Легального визначення терміна «правовий режим» у цивільному праві не існує, як немає і самого поняття правового режиму об'єктів цивільного права.

Питання щодо теоретичного рівня розробки категорії правового режиму в науці цивільного права піднімав свого часу ще 0.О. Красавчиков, який вказував на те, що загального поняття «правового режиму об'єктів цивільно-правових зв'язків» не сформульовано, а практично, і більше того, - іх немає взагалі. А коли і йдеться про правовий режим того чи іншого різновиду об’єктів цивільного права, то під цим завжди розуміють речі.

Якщо під час дослідження проблем правового режиму, наприклад, винахідницького права, у деяких авторів (до того ж не багатьох) іноді й зустрічається термін «правовий режим», то яке реальне явище відображає цей термін у разі, коли він застосовується в логічному зв'язку з винаходами, зрозуміти практично неможливо [1, с. 14-41]. 
B.I. Жуков в процесі дослідження поняття «правового режиму» стосовно нетілесних об'єктів цивільного права підходив із позиції «об'єкта-дії» («чужого»), поділяючи відомі погляди щодо цієї проблеми О.С. Іоффе та В.Я. Магазінера [2, с. 78].

У дійсності правовий режим встановлюється не для речей, а для пов'язаної з ними поведінки людей. Але оскільки речі є матеріальним об'єктом цивільного права, а дії зобов'язаних осіб (в абсолютних правовідносинах) чи зобов'язаної особи (у відносних правовідносинах) - юридичним об'єктом, то законодавець, приймаючи закон, пов'язує із властивостями, які об'єктивно притаманні матеріальному об'єкту, певні правові наслідки.

Саме в цьому розумінні слід «читати» словосполучення «правовий режим» речей, але «інформація, як така» - не є річчю.

Взагалі інформація є досить нетиповим об'єктом для науки цивільного права. Визначення правового режиму нетипових об'єктів цивільного права, як зазначає В.І. Жуков, має певні складності. Науковець це показує на прикладі об'єктів інформатики, більшість яких розміщені за ланцюгом «знання-сила» і не мають чітко визначеного правового режиму.

Можливо тому до цього часу немає досить чіткої, сприйнятої науковим співтовариством вчених-цивілістів, «технології» дослідження нетипових об'єктів цивільного права, як немає і універсальної «моделі» правового режиму цих об'єктів [3, с. 191-197].

Це певною мірою можна віднести й до інформації, правовий режим якої визначити досить складно, а іноді практично неможливо, як, наприклад, для відкритої (загальновідомої) інформації.

Під правовим режимом інформації, а також конфіденційної інформації (у вигляді комерційної таємниці та ноу-хау), слід розуміти «врахування» законодавцем природних властивостей і ознак, які їм притаманні.

Саме 3 цими властивостями чинне цивільне законодавство й пов'язує певні правові наслідки.

Однак проблема полягає ще й у тому, що, по-перше, термін «інформація» не є винятково юридичним терміном і їй (інформаціï) притаманні такі властивості-ознаки, які визначають їі правовий режим і цивільному праву взагалі невідомі. По-друге, різним видам інформації притаманні свої особливі ознаки, відмінні від ознак «інформації, як такої».

Згідно з чинним законодавством за порядком доступу інформація поділяється на: 1) відкриту інформацію та 2) інформацію з обмеженим доступом (ч. 1 ст. 20 Закону України «Про інформацію»).

Інформація 3 обмеженим доступом своєю чергою поділяється на: а) конфіденційну; б) таємну та в) службову (ч. 1 ст. 21 Закону України «Про інформацію») [4]. При цьому конфіденційна інформація включає в себе комерційну таємницю та ноу-хау, а таємна у вигляді державної таємниці регулюється відповідним законодавством [5].

Що ж стосується службової інформації, то не так давно вона виділена окремо, хоча за своєю суттю також є різновидом конфіденційної інформації, яка має специфічні ознаки-властивості.

Закон України «Про інформацію» не містить визначення поняття «правового режиму» інформації, але закріпив термін «порядок доступу» до інформації (ч. 1 ст. 20).

Як зазначають окремі науковці, визначити правовий режим інформації досить складно, а іноді й зовсім неможливо у зв'язку 3 тим, що не може існувати єдиного правового режиму для різних видів інформації.
Це правильно, оскільки щодо відкритої інформації діють принципи відкритості, доступності, свободи обміну інформацією (ст. 2 Закону України «Про інформацію») [6], що ускладнює визначення правового режиму такої інформації.

Характеризуючи ознаки, варто зазначити наступне. Важливість (цінність) інформації зумовлюються ії змістом і відповідною позитивною або негативною значимістю для суб' єктів права.

В цілому вона визначається не за якісними або кількісними властивостями інформації, а за їі місцем у сфері особливих інтересів суб'єктів права.

Встановлення правового режиму обмеженого доступу до інформації є результатом реалізації домовленостей сторін відносно такої інформації, що закріплюється нормами законодавства.

При цьому деякі цивільно-правові можливості (які надаються суб'єкту цивільним правом) можуть бути поглинуті відповідними заборонами, які встановлені, наприклад, засобами адміністративного або кримінального права. Таким чином, можливою є ситуація застосування цивільно-правових способів захисту проти необгрунтовано (з точки зору цивільного права) встановлених адміністративних заборон, кримінально-правових обмежень тощо.

Правовий режим інформації як об' єкта цивільного права наразі є досить актуальним питанням. У доктрині цивільного права існують різні позиції щодо цього. Тому метою є визначення базових посилок підходу щодо розуміння терміна «правовий режим» у науці цивільного права.

Для досягнення поставленої мети вирішуються такі завдання: дослідити теоретичний рівень розробки категорії «правовий режим» у науці цивільного права та визначити, що слід розуміти під правовим режимом інформації як об'єкта цивільного права.

Легального визначення терміна «правовий режим» у цивільному праві не існує, як немає і самого поняття правового режиму об'єктів цивільного права. Питання щодо теоретичного рівня розробки категорії правового режиму в науці цивільного права піднімав свого часу ще О.О. Красавчиков, який вказував на те, що загального поняття правового режиму об'єктів цивільно-правових зв'язків не сформульовано, а практично, і більше того, - їх немає взагалі.

А коли і йдеться про правовий режим того чи іншого різновиду об'єктів цивільного права, то під цим завжди розуміють речі. Якщо під час дослідження проблем правового режиму, наприклад, винахідницького права, у деяких авторів іноді й зустрічається термін «правовий режим», то яке реальне явище відображає цей термін у разі, коли він застосовується в логічному зв' язку з винаходами, зрозуміти практично неможливо.

Висновки. В межах поставленого завдання необхідно обрати і дослідити оптимальний правовий режим інформації (конфіденційної інформації), з урахуванням ії природних властивостей.

Однак це неможливо з ряду причин, по-перше, щодо «інформації, як такої» не може існувати єдиного правового режиму; по-друге, «інформація, як така» є багатогранним об'єктом, здатним перехрещуватися в різних правовідносинах і не тільки в цивільному праві; по-третє, механізм правового регулювання інформації (конфіденційної інформації) буде іншим - відмінним від речей і від об' єктів права інтелектуальної власності, оскільки жодним віндикаційним позовом чи законом про право інтелектуальної власності їх захистити не можна.

Насправді ж під правовим режимом інформації (конфіденційної інформації) слід розуміти «урахування» законодавцем природних властивостей і ознак, які їм притаманні та 3 якими цивільне законодавство може пов'язувати певні правові наслідки. 


\section{Jimepamypa:}

1. Правовой режим изобретений: постановка вопроса: сборник научных статей. Проблемы советского изобретательского права. Свердловск, 1983. 350 с.

2. Жуков В.И. Методология подхода к объектам информатики как к объектам гражданского правоотношения: сборник научных статей. Правовое государство. Проблемы правотворчества. Тарту, 1988. $260 \mathrm{c}$.

3. Правовой режим нетипичных объектов интеллектуальной собственности: сборник научных статей / Жуков В.И. Правовое государство. Проблемы правотворчества. Тарту, 1989. 256 с.

4. Про інформацію: Закон України: від 02.10.1992 № 2657-12 / Відомості Верховної Ради України. 1992. № 48. Ст. 650.

5. Про державну таємницю: Закон України: від 21.01.1994 № 3855-12/ Відомості Верховної Ради України. 1994. № 16. Ст. 93.

6. Про інформацію: Закон України: від 02.10.1992 № 2657-12 / Відомості Верховної Ради України. 1992. № 48. Ст. 650.

Костова Н. И. Информация с ограниченным доступом по своему нормативно-правовому режиму

Аннотация. Статья посвящена рассмотрению вопроса о теоретическом уровне разработки категории «информация по своему нормативно-правовому режиму» в науке гражданского права. В частности, было рассмотрено, что следует понимать под правовым режимом информации как объекта гражданского права, правовую природу и характерные признаки информации. Также рассмотрены разновидности информации, особенности установления правового режима информации, место информации в системе объектов гражданских прав.

Ключевые слова: информация с ограниченным доступом, правовой режим, информация, конфиденциальная информация, коммерческая тайна, ноу-хау.

Kostova N. Information with limited access to its regulatory regime

Summary. The article is devoted to the consideration of the theoretical level of the development of the category "information on its regulatory regime" in the science of civil law. In particular, it was considered what should be understood by the legal regime of information as an object of civil law, the legal nature and characteristic features of information. It also discusses the types of information, especially the establishment of the legal regime of information, the place of information in the system of objects of civil rights.

Key words: information with limited access, legal regime, information, confidential information, trade secrets, know-how. 